\title{
Distribution of species of the genus Stipa in Ukraine according to phytosociological databases
}

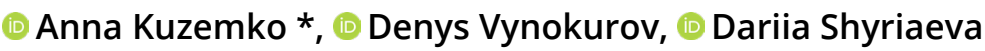 \\ M.G. Kholodny Institute of Botany, National Academy of Sciences of Ukraine, Tereshchenkivska str. 2, 01601 Kyiv, Ukraine; \\ * anyameadow.ak@gmail.com
}

Received: 28.10 .2020 | Accepted: 11.12.2020 | Published: 30.12.2020

\begin{abstract}
The paper presents the current distribution of species of the genus Stipa in Ukraine based on the data from phytosociological databases. The main objectives were to produce maps of distribution and to determine the affinity of Stipa species to EUNIS habitat classification units.

We succeeded in selecting the relevés with the participation of 16 out of 27 species of the genus Stipa recognized as a species in the "Nomenclature checklist of higher vascular plants of Ukraine". A total of 4888 relevés with the presence of Stipa were found. Stipa capillata has the most significant presence in the data set among other species of the genus. It was found in $38.1 \%$ of relevés. This species occupies second place in the analyzed data set by the Percentage Frequency and third place by Average Non-Zero Cover. According to the analysis of the distribution maps, it was established that S. capillata is a widespread species in the Forest-Steppe and the Steppe zones of Ukraine. Stipa lessingiana also has a significant distribution but is limited mainly to the Steppe zone. Both S. borysthenica and S. tirsa are significantly less present in the databases than reported in the literature, particularly in the Red Book of Ukraine and Green Book of Ukraine. Other species of the genus have limited distribution. Analysis of the habitat affinity of Stipa species showed that they occur in ten types of grassland habitats of the third level of the hierarchy according to the new version of the EUNIS classification. The vast majority of species have an ecological optimum in R1B - Continental dry grassland (true steppe). Stipa capillata has the widest amplitude in different habitat types. Also, a wide range of habitat types is characteristic for S. pulcherrima, S. lessingiana, S. pennata, and S. ucrainica. Species that are poorly represented in the dataset (S. zalesskii, S. transcarpatica, S. adoxa, S. asperella, and S. dasyphylla) occur in a few or only one habitat type.

Hence, our study shows that the vast majority of Stipa species in Ukraine are rare and need protection at the national level. However, the presence of S. capillata in the sample was very high. It was found in almost all types of dry grassland habitats, as well as in petrophytic, shrub, and even anthropogenic habitats. This is evidence of the high adaptability of the species and its wide ecological and coenotic amplitude. Our study results confirm the idea that $S$. capillata does not meet the criteria for inclusion to the national protection lists. It also suggests excluding this species from the Red Book of Ukraine, in case if the national legislation will regulate the protection of biodiversity at the superorganism level.
\end{abstract}

Keywords: dry grasslands, ecological optimum, EUNIS classification, expert system, habitats, percentage frequency, Red Book, steppe

\section{Introduction}

Humanity is entering an era of global environmental crisis, resulting in catastrophic biodiversity loss at all levels of its organization.
Thus, the documentation of localities of various living organisms and biological objects of the superorganism level - coenoses and ecosystems - becomes essential. An important 
and still underestimated source of such information is phytosociological databases, which are a repository of vegetation data (relevés) made on plots of a certain size, with a list of plant species and their cover or abundance. The main area of their implementation is vegetation classification. However, most modern relevés have a fairly accurate geographical reference, a detailed description of environmental conditions, and therefore can be used to solve a wide range of scientific issues, including documenting the localities of plants, both rare and common (Kuzemko, 2016; Iemelianova \& Kuzemko, 2017). Development of such databases on the continental (Chytrý et al., 2016) and global (Bruelheide et al., 2019) scales open new perspectives for such research. However, so far, such resources are insufficiently used in Ukraine to study the chorology of species, as lists of rare species are produced mainly based on floristic data, using herbaria, archival materials as well as literary sources. Some of these data are outdated and do not reflect the current distribution of many rare species.

We decided to focus on studying the current distribution of the genus Stipa L. (Poaceae), of which all the members are protected at the national level since 1996 (Shelyag-Sosonko, 1996; Didukh, 2009b) and are the dominants of the steppe vegetation in Ukraine. The recent revisions of the genus Stipa revealed that it comprises more than 150 species distributed in Europe, Asia, and North Africa (Romashchenko et al., 2012; Nobis et al., 2020). Different authors reported different numbers of feathergrass species for the territory of Ukraine and considered their volume differently. In the Flora of the USSR, Lavrenko (1940) provided eight species. Later, Klokov \& Osychnyuk (1976) indicated 29 Stipa species, many of which they described for the first time for science. However, in the next year, the monograph "Cereals of Ukraine" including only 13 Stipa species was published (Slyusarenko, 1977). Tzvelev (1986) consolidated both publications and reported 21 species of feather-grass from Ukraine. In the "Identification key to higher plants of Ukraine", Prokudin (1987) reported 13 species, which almost wholly coincided with Tzvelev (1986). The "Vascular plants of Ukraine. A nomenclatural checklist" (Mosyakin \& Fedoronchuk, 1999) recognizes 27 species of the genus.
In recent years, the taxonomic and phylogenetic structure of the genus Stipa, as well as the evolutionary role of the tribe Stipeae Dumort. in the formation of steppe biomes has been reconsidered basing on molecular and micromorphological data (Didukh et al., 2016; Romashchenko et al., 2012).

Unfortunately, the current state of distribution for the vast majority of Stipa species in Ukraine is unknown. Therefore, we set a goal to find it out using phytosociological databases. In particular, our main objectives were i) to obtain a list of localities of Stipa species in Ukraine and to produce maps of their distribution, in which to indicate current data (after 2000) based exclusively on phytosociological data, ii) to determine the affinity of Stipa species to EUNIS habitat classification units and to reveal optimal habitats for each species.

\section{Material and methods}

The vegetation plots from two phytosociological databases, Ukrainian Grassland Database (further UGD) (Kuzemko, 2012) and Eastern European Steppe Database (further EESD) (Vynokurov et al., 2020), served as sources of data for our investigation. These databases are registered in GIVD and EVA with registration numbers EU-UA-001 and EU00-030, respectively, and as of the beginning of October 2020 include a total of 18,719 vegetation plots. The selection criteria for the analysis were: i) the presence of Stipa species in the plot regardless of what habitat type the plot belongs to, and ii) assignment of a plot to the R1 habitat type (dry grasslands) according to the new version of EUNIS (Schaminée et al., 2019) regardless of whether Stipa species are present in it or not. The assignment of the plots to the units of the EUNIS system was determined using the EUNIS-ESy expert system (Chytrý et al., 2020) in the Juice program (Tichý, 2002). Thus, 8966 relevés were selected, of which 4841 were from UGD and 4125 from EESD. Next, 5869 georeferenced points of 16 Stipa species with the relevé dates were selected from the total dataset for mapping, as well as plots of the distribution by EUNIS units and an Average Non-zero cover (in percent) for each Stipa species in each habitat type on third (for R group) or first 
Table 1. Number and percentage frequency of vegetation plots with Stipa species in the general dataset.

\begin{tabular}{lllll}
\hline № & Species name & Absolute number & Georeferences, \% & $\begin{array}{l}\text { Percentage } \\
\text { Frequency, \% }\end{array}$ \\
\hline 1 & S. adoxa Klokov \& Ossycznjuk & 1 & 100.00 & 0.01 \\
2 & S. asperella Klokov \& Ossycznjuk & 69 & 100.00 & 0.77 \\
3 & S. borysthenica Klokov ex Prokudin & 96 & 100.00 & 1.07 \\
4 & S. brauneri (Pacz.) Klokov & 24 & 100.00 & 0.27 \\
5 & S. capillata L. & 3416 & 94.53 & 38.10 \\
6 & S. dasyphylla (Czern. ex Lindem.) Trautv. & 22 & 95.45 & 0.25 \\
7 & S. graniticola Klokov & 78 & 100.00 & 0.87 \\
8 & S. lessingiana Trin. \& Rupr. & 1198 & 96.83 & 13.36 \\
9 & S. lithophila P. Smirn. & 60 & 96.67 & 0.67 \\
10 & S. pennata L. & 282 & 85.82 & 3.15 \\
11 & S. poëtica Klokov & 57 & 78.95 & 0.64 \\
12 & S. pulcherrima K. Koch & 386 & 94.04 & 4.31 \\
13 & S. tirsa Steven & 115 & 93.04 & 1.28 \\
14 & S. transcarpatica Klokov & 1 & 100.00 & 0.01 \\
15 & S. ucrainica P. Smirn. & 1134 & 98.85 & 12.65 \\
16 & S. zalesskii Wilensky & 12 & 100.00 & 0.13 \\
\hline
\end{tabular}

(for $\mathrm{H}, \mathrm{S}$ and $\mathrm{V}$ groups) hierarchy level were calculated in the Juice program. Thematic vector layers for each species and cartographic materials based on them were produced using QGIS 3.10. software package. Vector boundaries of the administrative structures and hydrographic network on Ukraine's territory for illustrations were created using data from the OpenStreetMap project (www. openstreetmap.org) under the terms of the Open Database license.

\section{Results}

We revealed 16 species of the genus Stipa (Table 1) out of 27 recognized as a species by Mosyakin \& Fedoronchuk (1999): S. adoxa Klokov \& Ossycznjuk, S. anomala P. Smirn. ex Roshev., S. asperella Klokov \& Ossycznjuk, S. borysthenica Klokov ex Prokudin, S. brauneri (Pacz.) Klokov, S. capillata L., S. dasyphylla (Czern. ex Lindem.) Trautv., S. graniticola Klokov, S. lessingiana Trin. \& Rupr., S. lithophila P. Smirn., S. pennata L., S. poëtica Klokov, S. pulcherrima K. Koch, S. tirsa Steven, S. transcarpatica Klokov, S. ucrainica P. Smirn., and S. zalesskii Wilensky. Of the species that have an accepted status in the Euro+Med PlantBase (2020), we did not find any plots with S. donetzica Czupryna, S. fallacina Klokov \& Ossycznjuk, S. majalis Klokov, S. martinovskyi Klokov, S. oreades Klokov, and S. syreistschikowii P. Smirn.

The species understandings were taken mostly following Mosyakin \& Fedoronchuk (1999) and Euro+Med PlantBase (2020). However, based on the most recent studies (Nobis et al., 2020), we assigned S. anomala to $\mathrm{S}$. borysthenica synonyms because they have similar habitat types (sandy grasslands) and range of distribution. We also decided to keep other species that have an ambiguous nomenclatural status but have distinct habitat type or distribution range. Among them is $\mathrm{S}$. brauneri, which is distributed in Ukraine mainly within the Crimean Peninsula, whereas S. lessingiana to which S. brauneri is synonymized by Nobis et al. $(2016,2020)$ has a wide range of distribution throughout the entire Steppe zone. Similarly, S. graniticola is usually synonymized to S. pennata (Gonzalo et al., 2013) or S. borysthenica (Euro+Med PlantBase, 2020). Nevertheless, it is ecologically and geographically distinct because it grows only on granite outcrops and occurs only in the 
Table 2. Species with the highest Percentage Frequency $(>20 \%)$ in the general dataset $(N=8966)$ and Average Non-Zero Cover of them.

\begin{tabular}{llll}
\hline Rank & Species & Percentage Frequency & Average Non-Zero Cover \\
\hline 1 & Festuca valesiaca aggr. & 56 & 13.5 \\
2 & Stipa capillata & 38 & 9.8 \\
3 & Eryngium campestre & 36 & 1.9 \\
4 & Koeleria cristata & 35 & 4.7 \\
5 & Poa angustifolia & 29 & 12.3 \\
6 & Artemisia austriaca & 28 & 3.1 \\
7 & Euphorbia seguierana & 26 & 2.0 \\
8 & Teucrium chamaedrys & 24 & 9.2 \\
9 & Medicago romanica & 23 & 3.9 \\
10 & Falcaria vulgaris & 22 & 1.6 \\
11 & Teucrium polium aggr. & 22 & 3.3 \\
12 & Poa bulbosa & 21 & 4.3 \\
13 & Securigera varia & 21 & 2.4 \\
\hline
\end{tabular}

Steppe zone within Dnipro Upland and Azov Upland in Ukraine. Stipa transcarpatica, which is supposed to be an endemic described from Chorna Hora Mt. in Transcarpathian Lowland, recently was reported from this region as S. pulcherrima subsp. crassiculmis (P.A. Smirn.) Tzvelev (Chytrý et al., 2019). We keep the name S. transcarpatica in this paper, but in our opinion, it needs further investigation. Finally, 16 Stipa species were considered for the analysis.

We are well aware that Stipa is a taxonomically difficult genus. Researchers often have to record sterile or poorly developed specimens in vegetation plots, which probably introduces more errors than those present in floristic literature. Analyzing the results of our study, we also encountered apparent errors, which prompted us to check the data in the KW herbarium, as well as in the relevant literature (where possible), and make appropriate adjustments to the original data. The situation is also complicated by the fact that the collection of herbarium data of plants listed in the Red Book of Ukraine (Didukh, $2009 b)$ without appropriate permits is illegal, so often the species recorded in relevés are not confirmed by herbarium specimens, although, in our opinion, for such taxonomically complex genera as Stipa, collection of herbarium material during sampling is mandatory. In view of this, we do not rule out a certain percentage of misidentifications of Stipa species that are likely to affect the reliability of our results, especially for species with a low distribution. However, given the relatively large dataset used for the analysis and the data verification we performed, we hope that this did not have a significant impact on the overall picture of the distribution of most species.

A total of 4888 relevés with Stipa species presence were revealed in the dataset. Most of them (3253 relevés or $66.6 \%$ of the total number of relevés with Stipa) contained only one Stipa species. However, some relevés recorded by Osychnyuk in 1976 in the Khomutovsky Steppe reserve containe two (1210 relevés, $24.8 \%$ ), three (414 relevés, $8.5 \%$ ), four (8 relevés, $0.16 \%$ ), and even five Stipa species. Stipa capillata has the highest presence frequency among all analyzed Stipa species since it was found in $38.1 \%$ of relevés. This species occupies the second position after Festuca valesiaca aggr. (56\%) in terms of appearance frequency in the analyzed dataset. Stipa capillata is also ahead with other dominants of steppe phytocoenoses, such as Koeleria cristata (L.) Pers. (35\%), Poa angustifolia L. (29\%), P. bulbosa L. (21\%), Elytrigia intermedia (Host) Nevski (14\%), and Botriochloa ischaemum (L.) Keng (12\%) (Table 2). Among other species of the genus, S. lessingiana (13.36\%), S. ucrainica P. Smirn (12.65\%), S. pulcherrima K. Koch (4.31\%), and 
S. pennata L. (3.15\%) also have a reasonably high presence in the dataset. For other species of the genus, the occurrence frequency does not exceed $1 \%$. A similar comparison of species in the dataset on Average Non-Zero Cover (Table 2) showed that with $9.8 \%$ S. capillata ranks third, after only Festuca valesiaca aggr. and Poa angustifolia. This is evidence of the high number and density of populations of this species.

Analysis of the distribution of Stipa species in Ukraine (Figs. 1-10) showed that one species - S. capillata is widespread in the ForestSteppe and Steppe zones. There are three isolated areas in the north of the Forest-Steppe - in Rivne, Kyiv, and Sumy oblasts, but most of these points are old - before 2000. However, the vast majority of points are modern. In the west of Ukraine, the limit of distribution of the species runs along the Dniester valley in Prykarpattia, and in the east - in the Luhansk oblast near the border with the Russian Federation. It is noteworthy that most of the Crimean Peninsula points are old, while recent ones are presented only on the Kerch Peninsula. Unfortunately, there is currently no way to fill this gap given the impossibility of research in Crimea due to annexation by the Russian Federation. Stipa lessingiana has a somewhat narrower but still wide distribution; its range is limited mainly to the Steppe zone in contrast to the previous species. The vast majority of points are modern, but in the south of Odesa oblast and in the Crimea - there are only historical data.

Two species mentioned before are significantly more common than three other (S. pennata, S. pulcherrima, and S. ucrainica), which, however, are quite widespread. Stipa pennata has the highest concentration of localities in the Dniester valley and its tributaries. Also its localities scattered throughout the Forest-Steppe, in particular in Central (Kyiv, Cherkasy, and Kirovohrad oblasts) and Eastern (Sumy oblast, and at the intersection of Kharkiv, Luhansk, and Donetsk oblasts) Ukraine. In the Steppe zone, this species is much less common and occurs in the north of Odesa and Mykolaiv oblasts; there is also a separate point in the south of Donetsk oblast. The vast majority of relevés with this species are modern, while most historical ones are from Sumy oblast, as well as one point from Rivne and Donetsk oblasts. Stipa pulcherrima is present in the relevés from most regions of the Forest-Steppe and Steppe zones of Ukraine. Most relevés with S. pulcherrima are available from the western (Ternopil and Khmelnytsky oblasts) and eastern (Luhansk oblast) regions. There are only a few historical relevés, and most of them are concentrated in the Crimean Mountains. Stipa ucrainica is distributed almost exclusively in the Steppe zone of Ukraine, and only in the Mykolaiv oblast along the valley of the river Southern Bug it reaches the border with the ForestSteppe. The greatest concentration of relevés with this species is observed in Kherson and Mykolayiv oblasts.

Interesting results were obtained regarding the distribution of relevés with S. borysthenica. Despite the fairly wide distribution reported in the Red (Didukh, 2009b) and Green (Didukh, 2009a) Books of Ukraine, this species is much less widespread according to the analyzed databases. Most modern points are concentrated in the lower Dnieper and Southern Bug rivers - in Mykolaiv and Kherson oblasts. Approximately the same situation with the distribution of S. tirsa - there are isolated localities in several (western, central, and eastern) regions. The obtained results indicate the need for a detailed study of the current distribution of these two species in Ukraine and confirmation of all known localities.

The rest of the species of the genus have very limited distribution. Thus, S. graniticola is represented by several sets of relevés from small areas of the Pivdennyi Bug basin in Mykolayiv and Kirovohrad oblasts, and near the river Berda in Zaporizhia oblast. All localities of this species are modern. Stipa dasyphylla has five modern localities, represented by several points each - four localities on the Dnieper Upland in Mykolayiv and Kirovohrad oblasts, and one - on the Azov Upland in Donetsk oblast. Stipa asperella has approximately the same distribution - several modern localities, mainly in Mykolaiv oblast, and one historical - in the south of Donetsk oblast. Modern relevés with S. brauneri (according to Nobis et al. (2020) it is considered as S. lessingiana var. brauneri (Pacz.) Roshev.) are concentrated on the Kerch Peninsula, and one historical is reported from the Azov Sea coast in Donetsk oblast. Stipa lithophylla is present both in historical and modern relevés from the Crimean Mountains. Stipa poëtica is known 


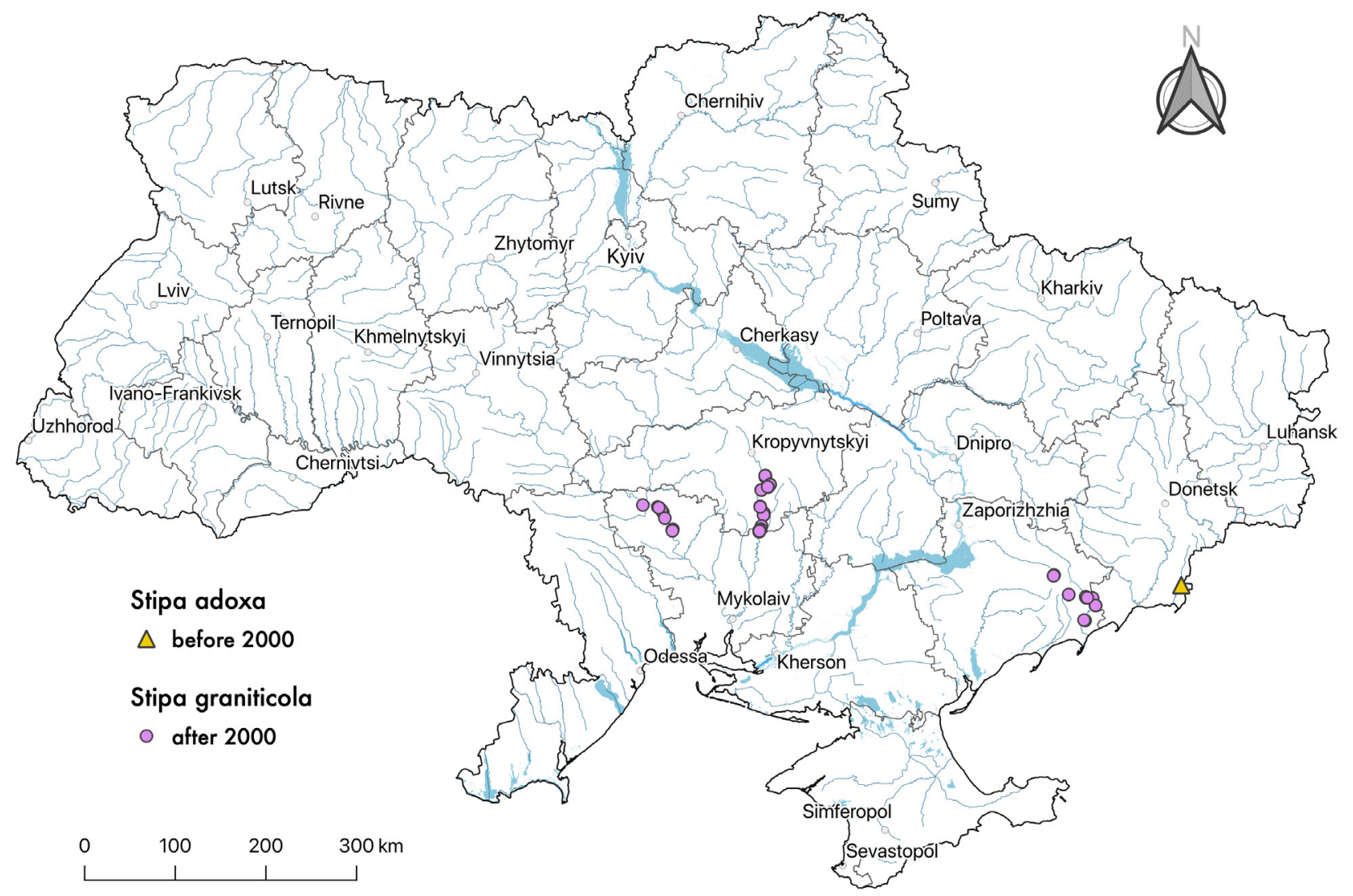

Figure 1. Distribution of Stipa adoxa and S. graniticola in Ukraine.

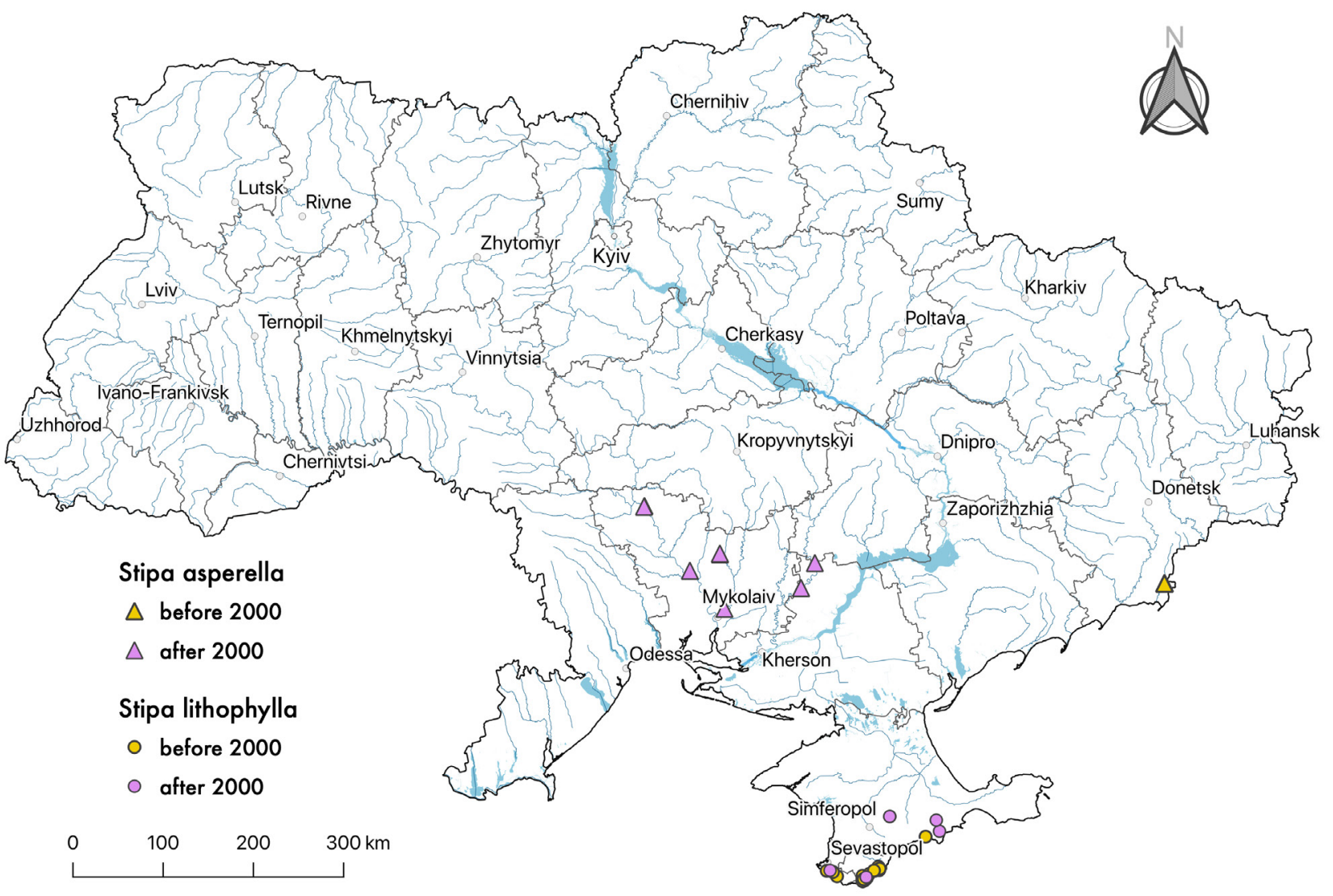

Figure 2. Distribution of Stipa asperella and S. lithophylla in Ukraine. 


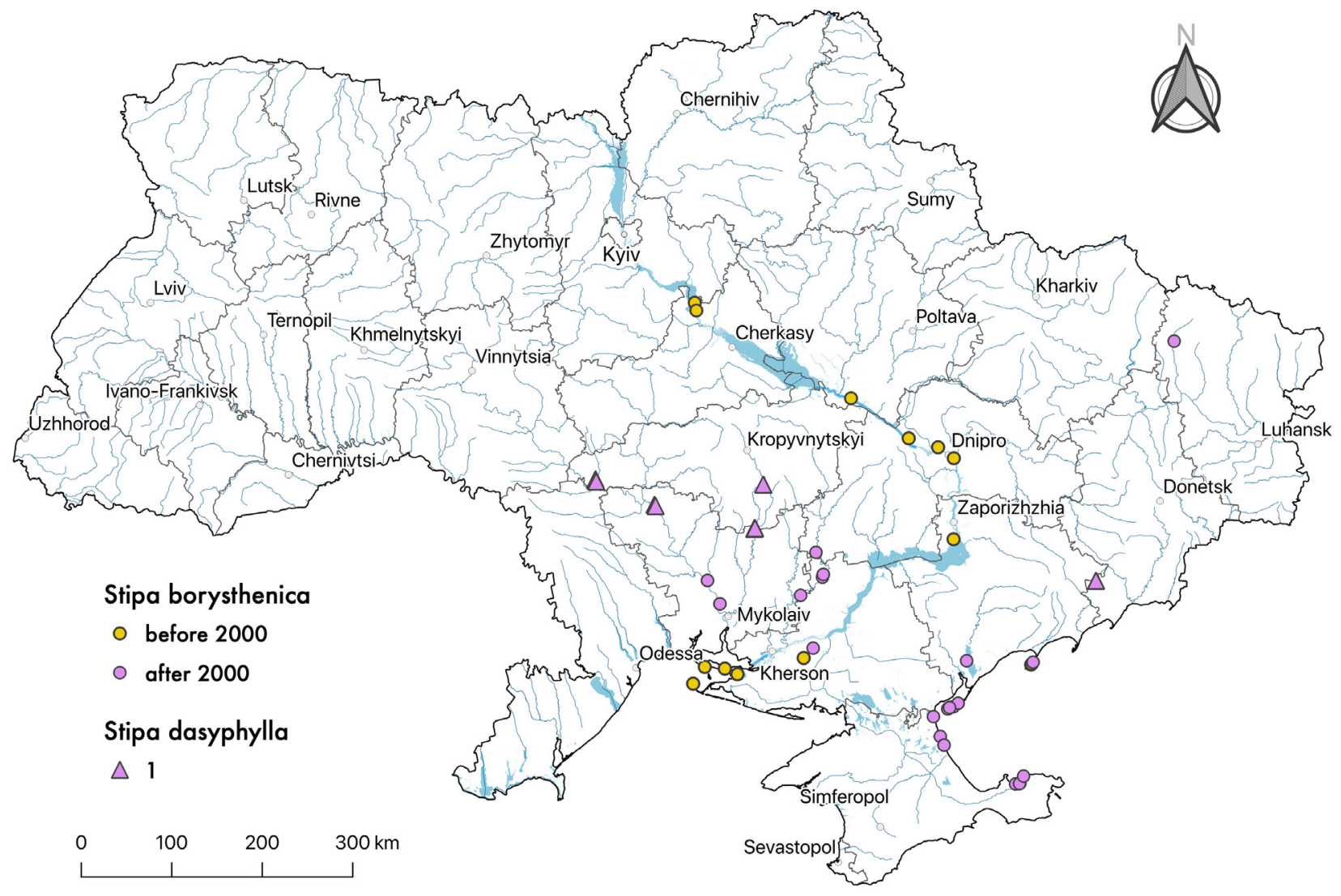

Figure 3. Distribution of Stipa borysthenica and S. dasyphylla in Ukraine.

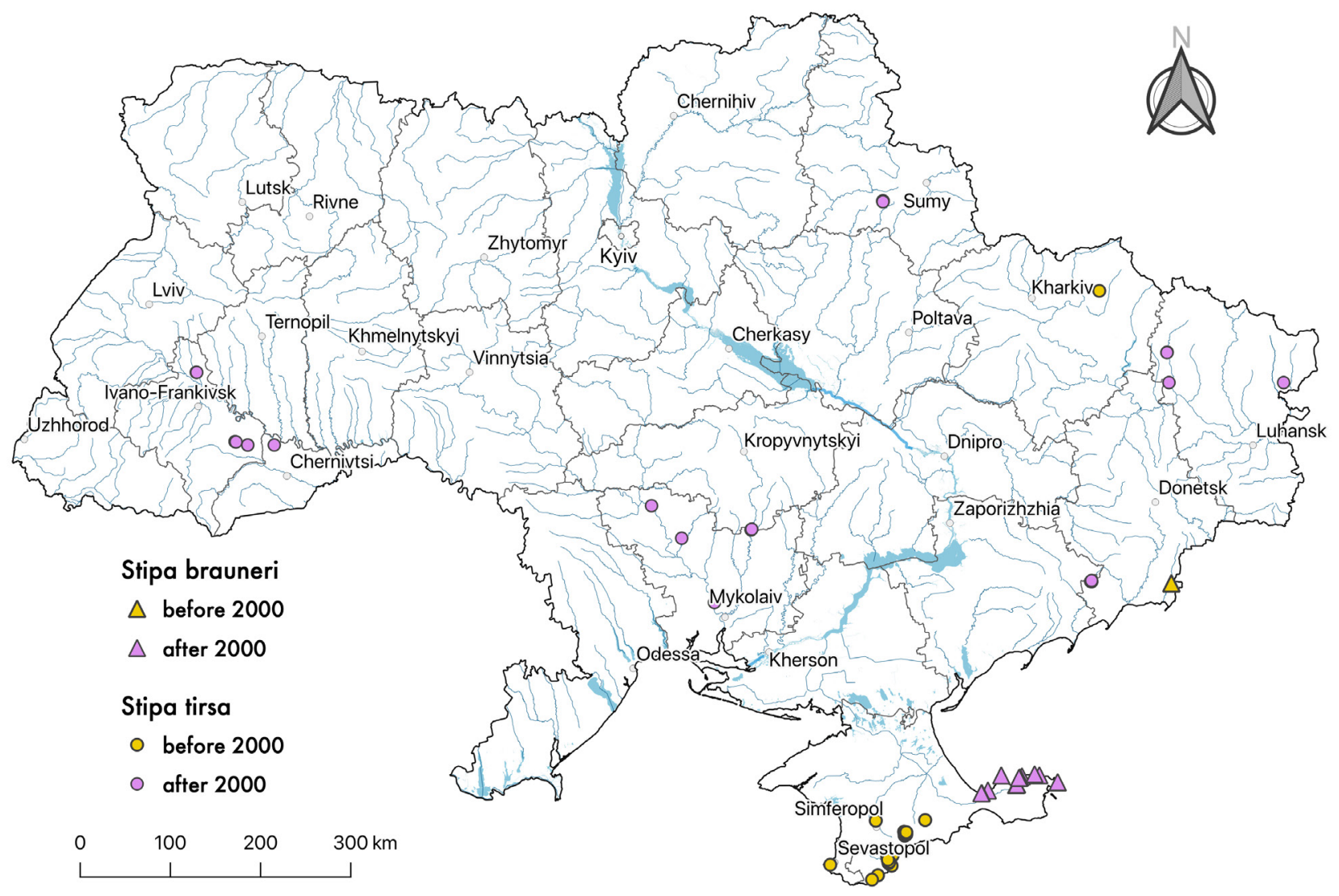

Figure 4. Distribution of Stipa brauneri and S. tirsa in Ukraine. 


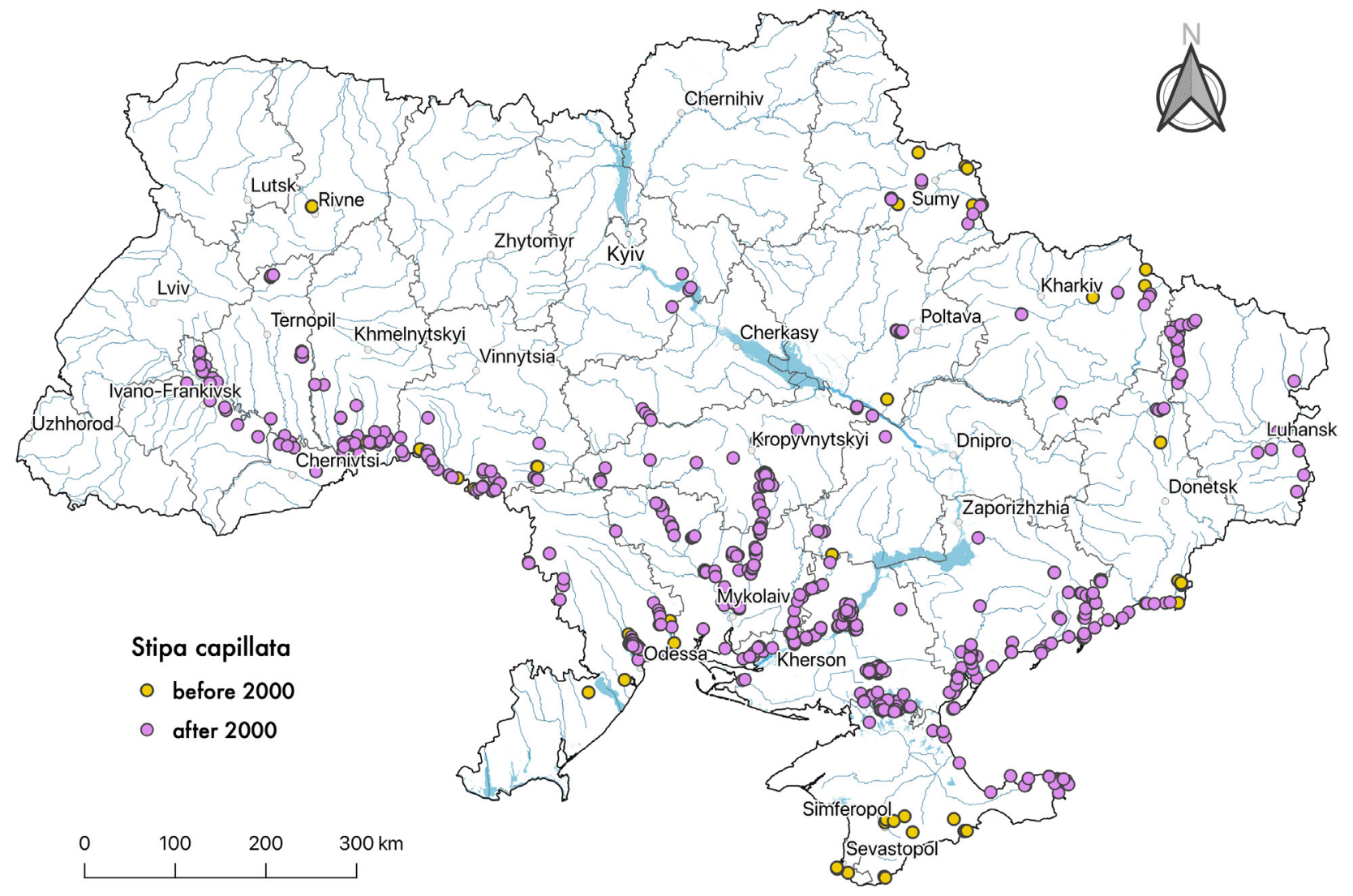

Figure 5. Distribution of Stipa capillata in Ukraine.

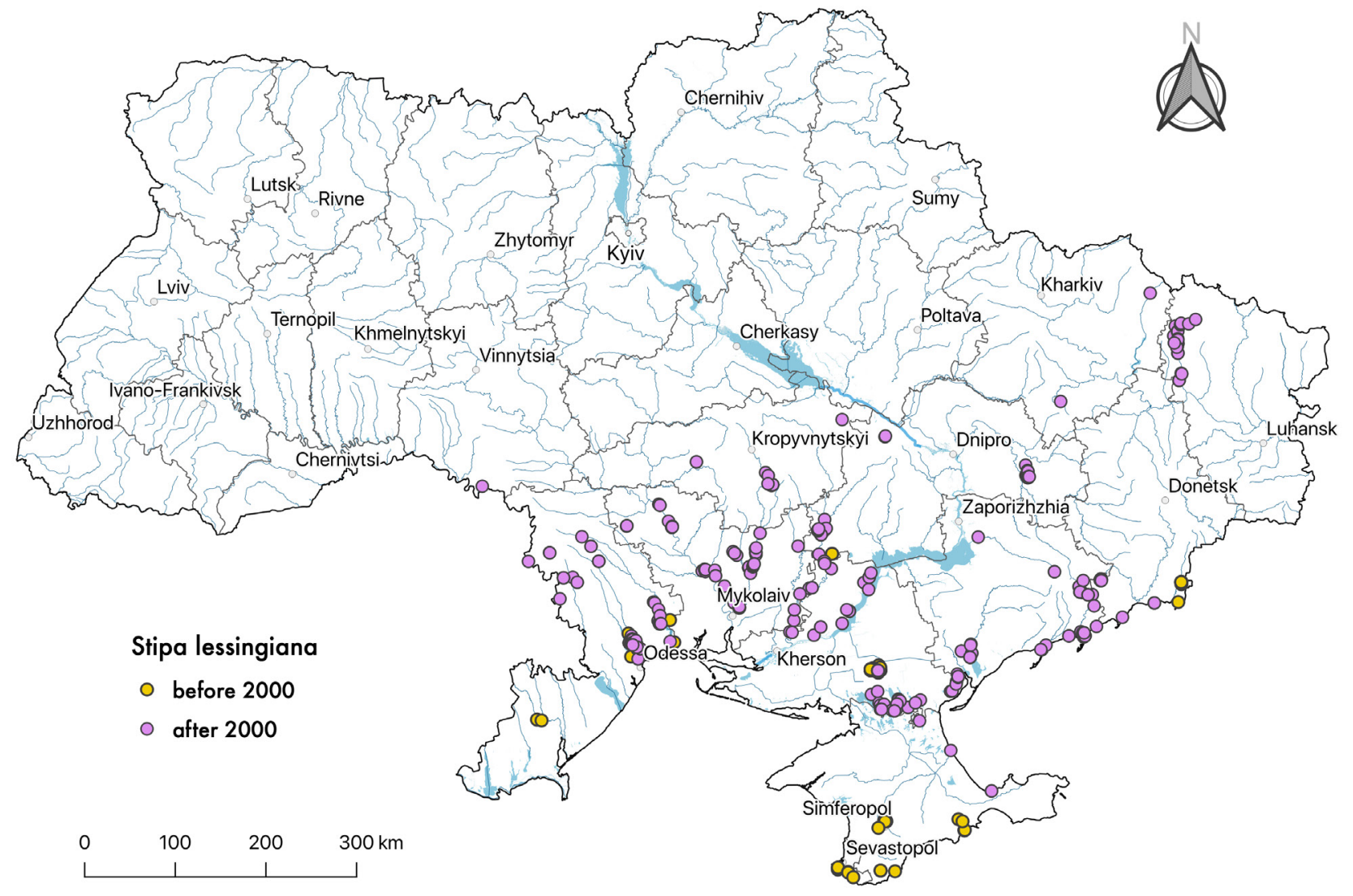

Figure 6. Distribution of Stipa lessingiana in Ukraine. 


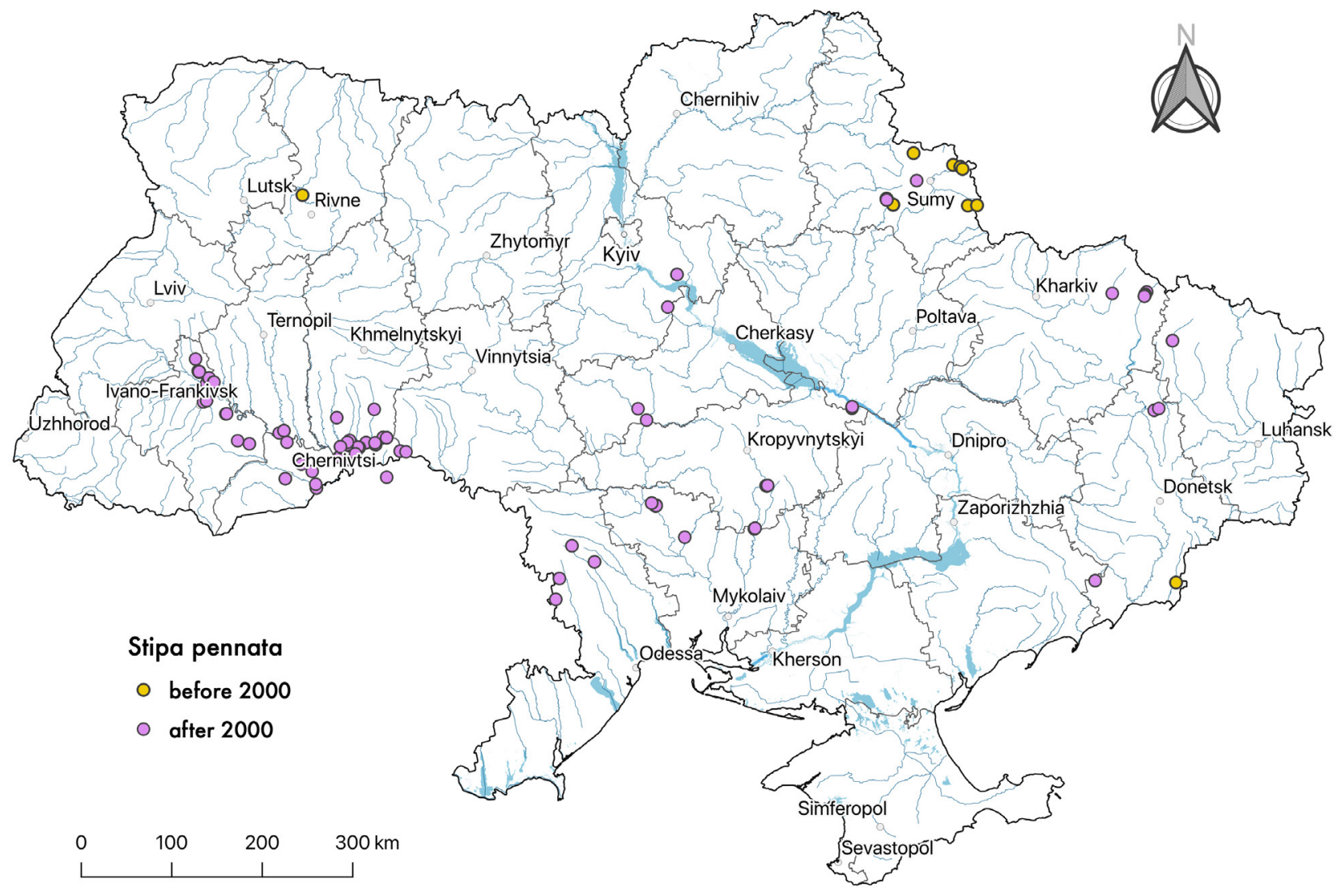

Figure 7. Distribution of Stipa pennata in Ukraine.

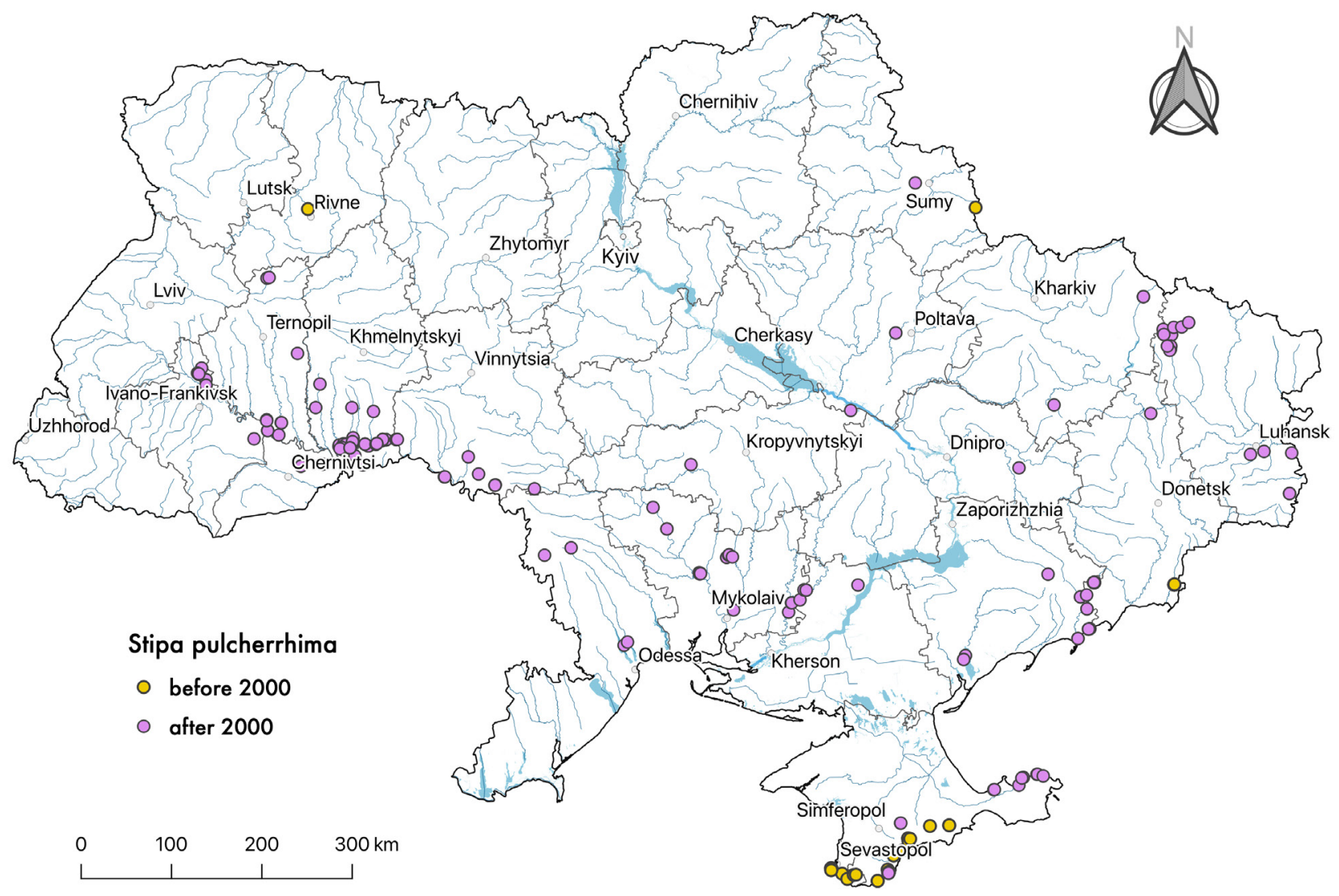

Figure 8. Distribution of Stipa pulcherrhima in Ukraine. 


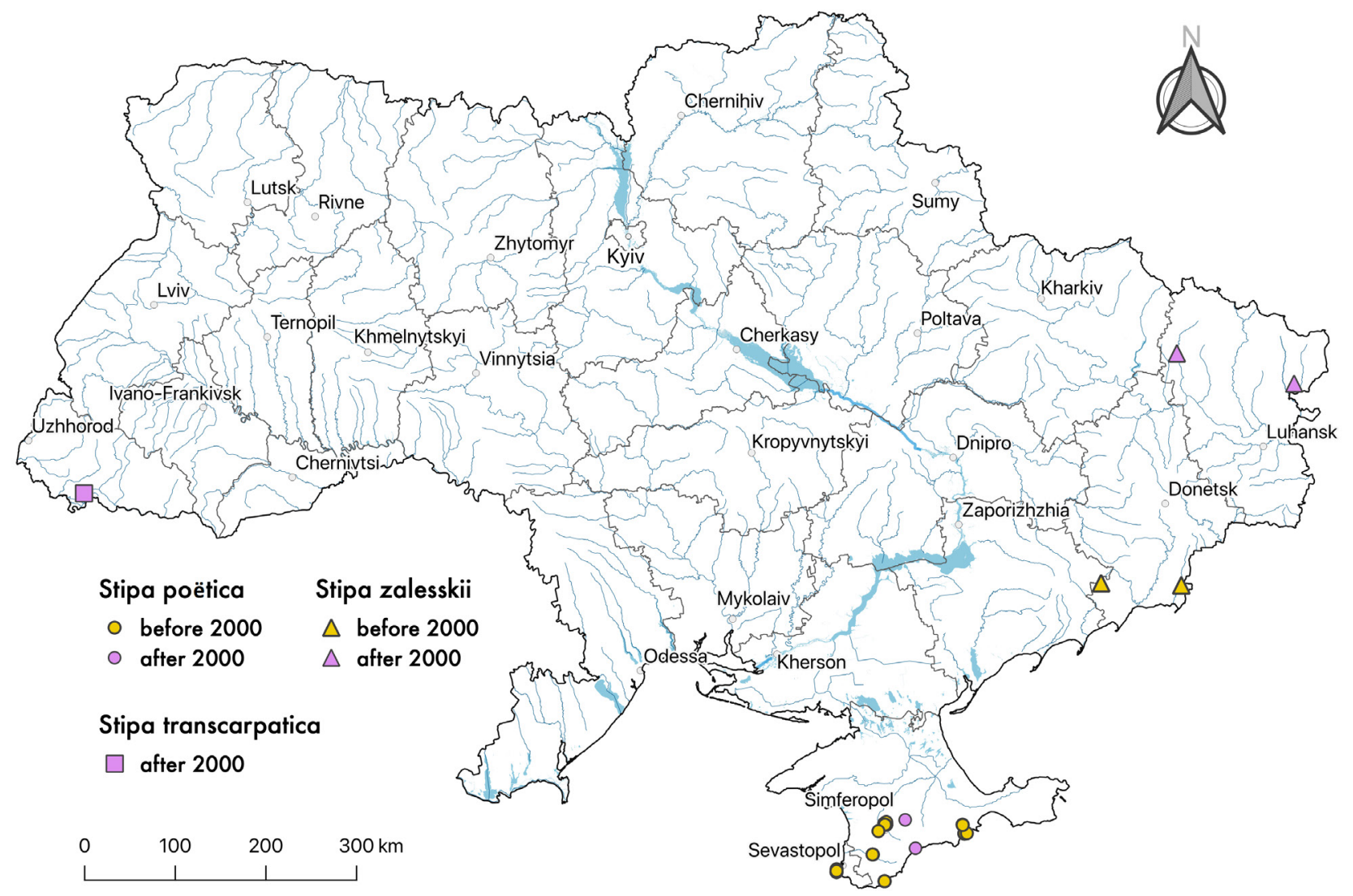

Figure 9. Distribution of Stipa poëtica, S. transcarpatica, and S. zalesskii in Ukraine.

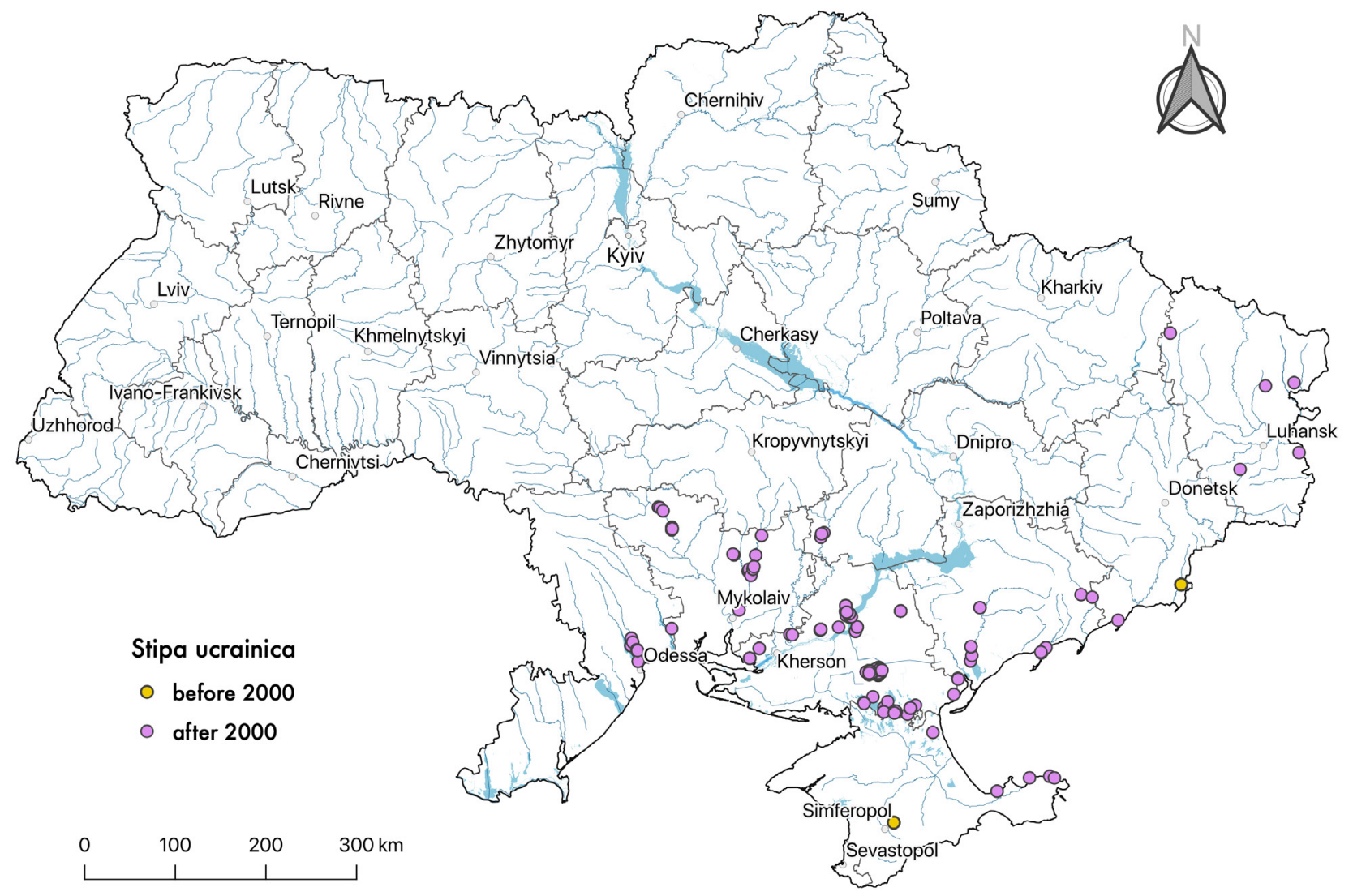

Figure 10. Distribution of Stipa ucrainica in Ukraine. 


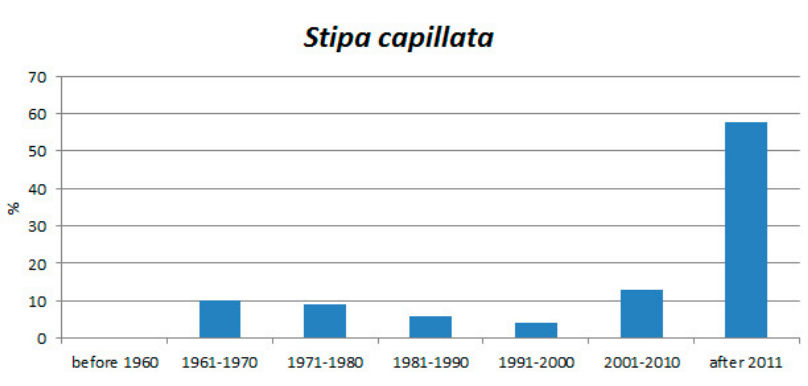

Stipa ucrainica

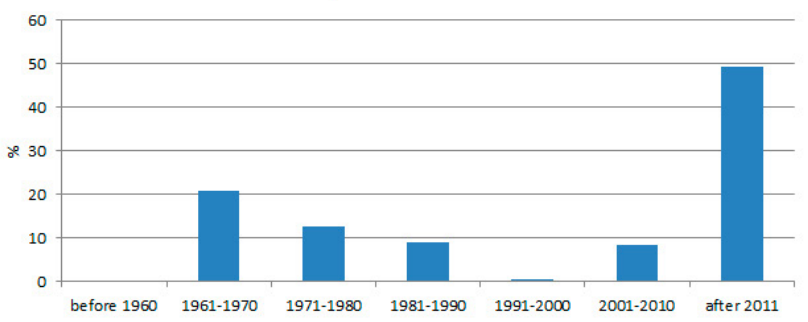

Stipa pennata

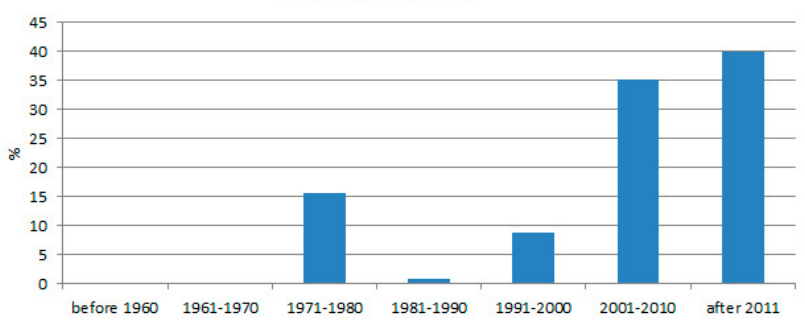

mainly from the Crimean historical relevés. Two historical relevés represent S. zalesskii in the Donetsk oblast and two modern ones - in the Luhansk oblast. Stipa transcarpatica is represented by one modern relevé in Zakarpattia oblast, and S. adoxa - by one historical relevé in Donetsk oblast.

The analysis of relevés with the five most common Stipa species in the dataset (Fig. 11) showed that most relevés (from $40 \%$ for S. pennata to $58 \%$ for S. capillata) were made during the last decade, which allows considering our data quite up-to-date.

Analysis of the habitat affinity of Stipa species (Table 3) showed that they occur in ten types of grassland habitats (group R, formerly E) of the third level of the hierarchy according to the EUNIS classification. As expected, the vast majority (15 of the 16 analyzed species) are present in the plots belonging to the habitat type R1B - Continental dry grassland (true steppe). Moreover, 11 species (S. adoxa, S. asperella, S. brauneri, S. capillata, S. dasyphylla, S. graniticola, S. lessingiana, S. pennata, S. pulcherrima, S. ucrainica, and S. zalesskii), have an

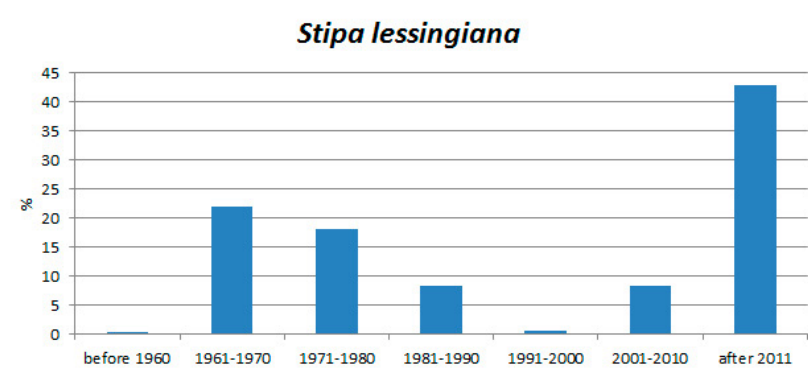

Stipa pulcherrima

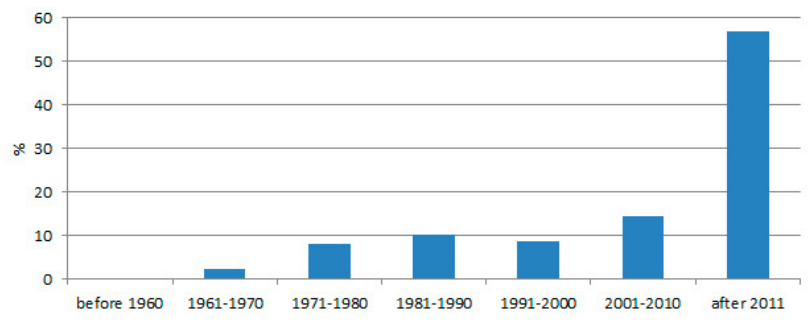

Figure 11. Distribution of plots with the five most common Stipa species by the year of relevé.

ecological optimum here, as evidenced by the highest proportions of relevés with these species in this habitat type. However, only five species (S. adoxa, S. asperella, S. brauneri, S. dasyphylla, and S. poëtica) have the highest average non-zero cover here. Nine Stipa species are represented in each of the types R15 - Continental dry rocky steppic grassland and dwarf scrub on chalk outcrops, and R1A - Semi-dry perennial calcareous grassland (meadow steppe). However, apparently due to extreme environmental conditions, no species has an optimum in the type R15, while the R1A type is optimal for S. lithophila and S. tirsa. Quite expectedly, the optimal type for S. borysthenica is R11 - Pannonian and Pontic sandy steppe, and for S. transcarpatica it is R13 - Cryptogam-and annual-dominated vegetation on calcareous and ultramafic rock outcrops.

In addition to grassland habitats, Stipa species are also present in three other habitat groups. Their presence in the habitats belonging to group $\mathrm{H}$ - Inland unvegetated or sparsely vegetated habitats is explained by the possibility of their transition from 


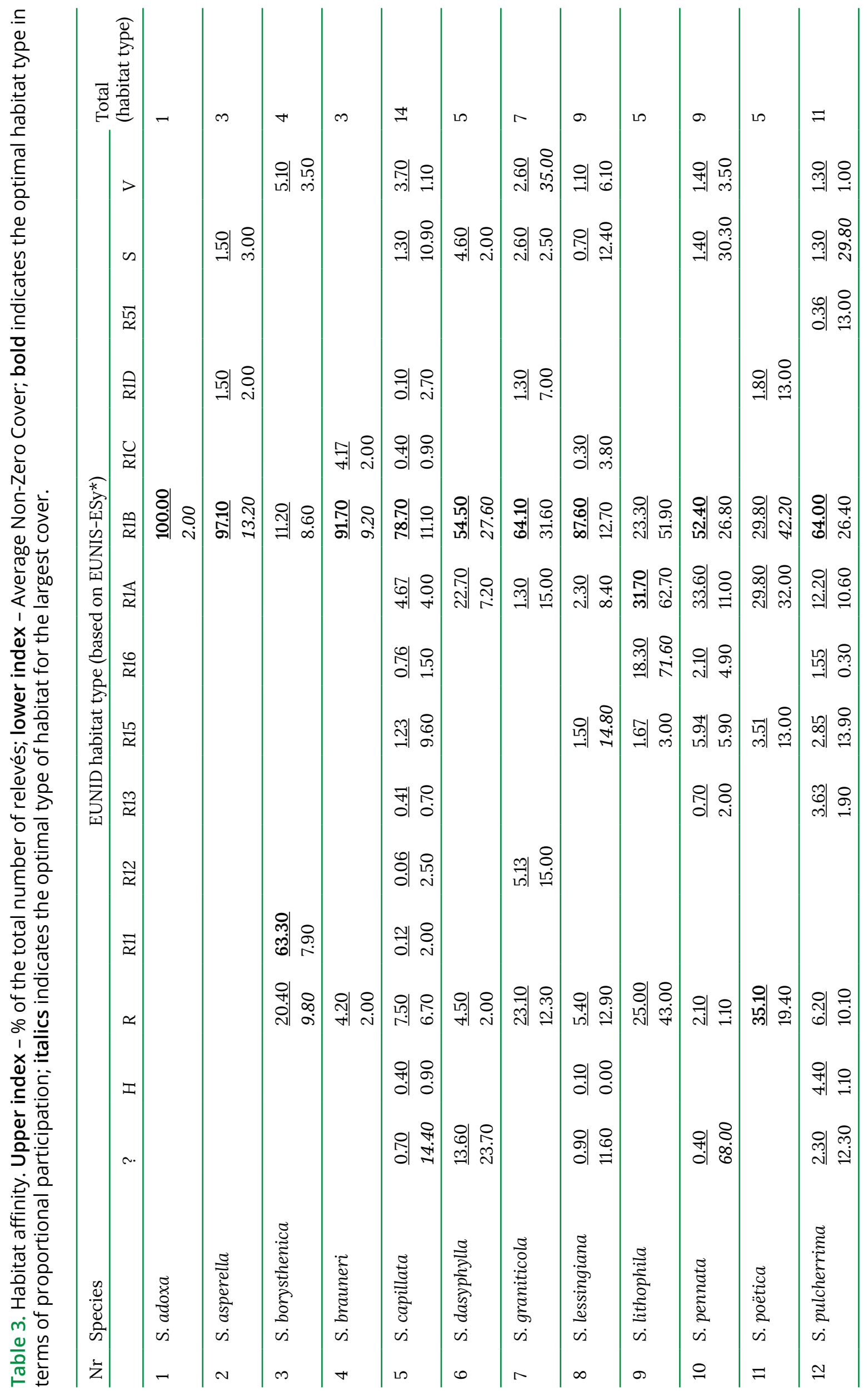




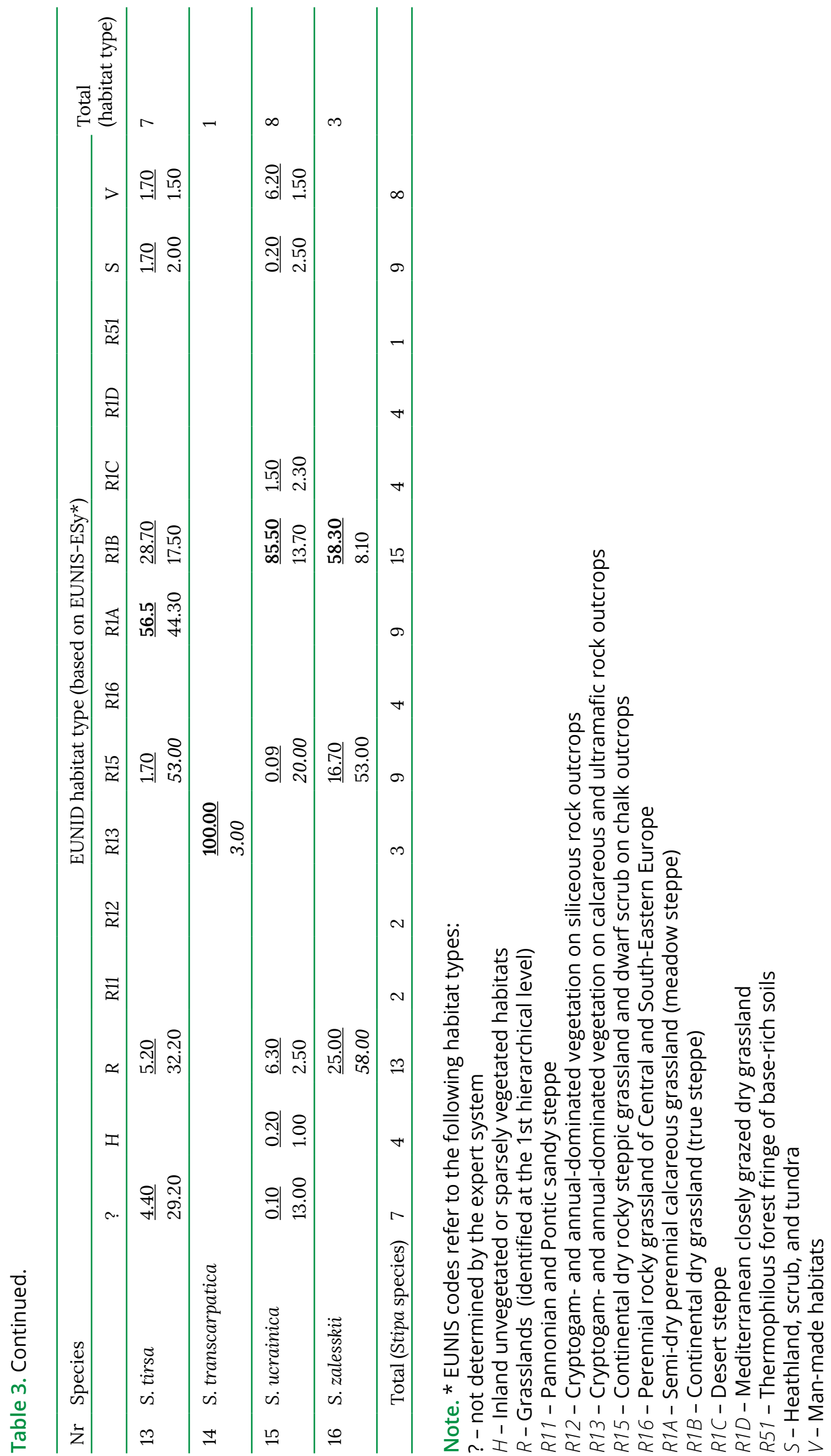


the habitats of petrophytic steppes to the outcrops adjacent to them. The overgrowth of steppes explains Stipa species' presence in shrub habitats (group $S$ ) with shrub vegetation due to natural succession. The presence of Stipa species in anthropogenic habitats (group V) is explained by the fact that there are steppe habitats at advanced digression stages.

Stipa species are also present in grassland habitats that have been classified at the first level of the hierarchy, as well as in habitats that have not been identified by the expert system. There may be several reasons for this - the incompleteness of relevés, the transitional nature of relevés between different types and groups of habitats, and the lack of habitat type in the existing classification system and, respectively, in the expert system. In particular, this relevant to the complex type X36 - Depressions (pody) of the Steppe zone.

Stipa capillata has the widest range of representation in different habitat types. This species is present in all types identified in the dataset, except R51 (Table 3). In general, there is a significant positive correlation between the occurence frequency of species in the dataset and the number of habitat types in which they are present. Therefore, it is not surprising that a wide range of habitat types is also characteristic for $\mathrm{S}$. pulcherrima, S. lessingiana, S. pennata, S. ucrainica, and vice versa - species that are poorly represented in the dataset occur in a few or only one type.

\section{Discussion}

Our results show that in Ukraine many Stipa species are rare and require protection at the national level. Particular attention should be paid to such species as S. adoxa and S. transcarpatica, which are present in the database in only one relevé each. As mentioned above, their taxonomic status requires further clarification. More detailed investigations also require $\mathrm{S}$. asperella, S. dasyphylla, and S. zalesskii, which have very limited distribution, as well as S. borysthenica and S. tirsa for which we revealed a contradiction in the reported distribution.
We noted that two species (S. lessingiana and $S$. capillata) are quite widespread in Ukraine, which raises a reasonable question about the feasibility of protecting these species at the national level. It should be noted that S. lessingiana is distributed mainly in the Steppe zone, and the vast majority of relevés with its participation (87.6\%) are concentrated in the true steppic habitats. This species' largest cover is noted in the plots belonging to R15 - Continental dry rocky steppic grassland and dwarf scrub on chalk outcrops. All this speaks against this species' exclusion from the next edition of the Red Book of Ukraine. Even for specialists, this species is sometimes difficult to recognize. Other persons making decisions about the organization of protection areas and planning their management could not distinguish it at all. It is very likely to confuse S. lessingiana with other Stipa species, which are much rarer. Hence, we consider it inappropriate to exclude this species from the Red Book of Ukraine (Didukh, 2009b). Thus, despite the relatively wide distribution of this species, many arguments, primarily practical, testify against its exclusion from the Red Book of Ukraine.

Another situation with S. capillata, whose presence in the dataset was very high (38\%). Even if we assume that the selection of sites for relevés could be made to some extent subjectively, the Percentage Frequency of this species in the dataset, which exceeds almost all, even common species of steppe communities, is an objective indicator of high representation of this species not only in the dataset but in Ukraine in general. Its presence in almost all types of dry grassland habitats, as well as in petrophytic, shrubs, and even anthropogenic habitat groups, indicates wide ecological and coenotic amplitude of the species. Also, this species of feather-grass is well distinguishable from other Stipa species, and even without special training, it can be easily identified.

In light of the wide-ranging debate surrounding the possible exclusion of some species from the Red Book of Ukraine (Didukh, 2009b), our data rather support the proposals of the National Commission for the Red Book of Ukraine to exclude S. capillata from the new edition. However, it should be noted that in the new edition, the 
criteria for the inclusion of species should be formulated more clearly than in the previous. In our opinion, for this purpose, it would be appropriate to use IUCN criteria (IUCN Species Survival Commission, 2012) for the inclusion of plant species in the national protection lists (Le Breton et al., 2019). The application of such quantitative criteria and evaluation of all species, including Stipa species, according to these criteria will allow to make an informed decision on the inclusion or exclusion of a species from the Red Book of Ukraine, as well as to avoid possible speculation and predominance of political, socio-economic and others, not always relevant factors, over scientific ones. The data presented in our paper can provide a factual basis for the assessment of Stipa species according to IUCN criteria.

\section{References}

Bruelheide, H., Dengler, J., Jiménez-Alfaro, B., Purschke, O., Hennekens, S. M., Chytrý, M., Pillar, V. D., Jansen, F., Kattge, J., Sandel, B., Aubin, I., Biurrun, I., Field, R., Haider, S., Jandt, U., Lenoir, J., Peet, R. K., Peyre, G., Sabatini, F. M., ... Zverev, A. (2019). sPlot - A new tool for global vegetation analyses. Journal of Vegetation Science, 30(2), $161-186$. https://doi. org/10.1111/jvs.12710

Chytrý, K., Novák, P., Kalníková, V., Večeřa, M., Prokešová, H., Dřevojan, P., \& Chytrý, M. (2019). Dry grassland vegetation in the Transcarpathian Lowland (Western Ukraine). Tuexenia, 39, 335355. https://doi.org/10.14471/2019.39.009

Chytrý, M., Hennekens, S. M., Jiménez-Alfaro, B., Knollová, I., Dengler, J., Jansen, F., Landucci, F., Schaminée, J. H. J., Aćić, S., Agrillo, E., Ambarlı, D., Angelini, P., Apostolova, I., Attorre, F., Berg, C., Bergmeier, E., Biurrun, I., Botta-Dukát, Z., Brisse, H., ... Yamalov, S. (2016). European Vegetation Archive (EVA): An integrated database of European vegetation plots. Applied Vegetation Science, 19, 173-180. https://doi.org/10.1111/avsc.12191

Chytrý, M., Tichý, L., Hennekens, S. M., Knollová, I., Janssen, J. A. M., Rodwell, J. S., Peterka, T., Marcenò, C., Landucci, F., Danihelka, J., Hájek, M., Dengler, J., Novák, P., Zukal, D., Jiménez-Alfaro, B., Mucina, L., Abdulhak, S., Aćić, S., Agrillo, E., ... Schaminée, J. H. J. (2020). EUNIS Habitat Classification: Expert system, characteristic species combinations and distribution maps of European habitats. Applied Vegetation Science, 23(4), 648-675. https://doi.org/10.1111/avsc.12519
Didukh, Y. P. (Ed.). (2009a). Green book of Ukraine. Kyiv: Alterpress (In Ukrainian)

Didukh, Y. P. (Ed.). (2009b). Red Book of Ukraine. Plant world. Kyiv: Globalkonsalting. (In Ukrainian)

Didukh, Y. P., Romashchenko, K. Y., Futorna, O. A. (2016). Stages of the evolution of the genus Stipa and the formation of steppes. Ukrainian Botanical Journal, 73(1), 21-32. (In Ukrainian). https://doi. org/10.15407/ukrbotj73.01.021

Euro+Med PlantBase. (2020). The information resource for Euro-Mediterranean plant diversity. 2011-onward. Retrieved from https://www. emplantbase.org/home.html

Gonzalo, R., Aedo, C., \& García, M. Á. (2013). Taxonomic revision of the Eurasian Stipa subsections Stipa and Tirsae (Poaceae). Systematic Botany, 38(2), 344-378. https://doi. org/10.1600/036364413X666615

Iemelianova, S. M., \& Kuzemko, A. A. (2017). National phytosociological database of Ukraine (UKRVEG): The relevance of creation and problems of development. In Proceedings of the Second Ukrainian Scientific-theoretical Conference "Classification of vegetation and habitats of Ukraine as a scientific basis for biodiversity conservation" (pp. 24-37). (In Ukrainian)

IUCN Species Survival Commission. (2012). IUCN Red List categories and criteria, version 3.1, 2nd edition. Gland and Cambridge: IUCN. Retrieved from https://portals.iucn.org/library/node/10315

Klokov, M. V., \& Osychnyuk, V. V. (1976). Feather grass of Ukraine. In Taxonomy news of higher and lower plants - 1975. Kyiv: Naukova Dumka. (In Russian)

Kuzemko, A. A. (2012). Ukrainian Grasslands Database. Biodiversity \& Ecology, 4(Sp. Vol. Vegetation databases for the 21st Century), 430430. https://doi.org/10.7809/b-e.00217

Kuzemko, A. A. (2016). The role of phytosociological databases in preparation of the new edition of the Red Data Book of Ukraine. In Proceedings of the 4th International Conference "Rare Plants and Fungi of Ukraine and Adjacent Areas" (pp. 38-41). Palyvoda. (In Ukrainian)

Lavrenko, Y. M. (1940). Stipa L. genus - Feather grass. In Y. M. Lavrenko (Ed.), Flora of the UkrSSR. Vol. 2. (pp. 117 -131). Kyiv: AS of UkrSSR. (In Ukrainian)

Le Breton, T. D., Zimmer, H. C., Gallagher, R. V., Cox, M., Allen, S., \& Auld, T. D. (2019). Using IUCN criteria to perform rapid assessments of at-risk taxa. Biodiversity and Conservation, 28, 863-883. https://doi.org/10.1007/s10531-019-01697-9

Mosyakin, S. L., \& Fedoronchuk, M. M. (1999). Vascular plants of Ukraine. A nomenclatural checklist. Kyiv: M.G. Kholodny Institute of Botany. 
Nobis, M., Gudkova, P. D., Nowak, A., Sawicki, J., \& Nobis, A. (2020). A synopsis of the genus Stipa (Poaceae) in Middle Asia, including a key to species identification, an annotated checklist, and phytogeographic analyses. Annals of the Missouri Botanical Garden, 105(1), 1-63. https:// doi.org/10.3417/2019378

Nobis, M., Klichowska, E., Nowak, A., Gudkova, P. D., \& Rola, K. (2016). Multivariate morphometric analysis of the Stipa turkestanica group (Poaceae: Stipa sect. Stipa). Plant Systematics and Evolution, 302(2), 137153. https://doi.org/10.1007/s00606-015-1243-9

Prokudin, Y. N. (Ed.). (1987). Identification key to higher plants of Ukraine. Kyiv: Naukova Dumka. (In Russian)

Romashchenko, K., Peterson, P. M., Soreng, R. J., Garcia-Jacas, N., Futorna, O., \& Susanna, A. (2012). Systematics and evolution of the needle grasses (Poaceae: Pooideae: Stipeae) based on analysis of multiple chloroplast loci, ITS, and lemma micromorphology. Taxon, 61(1), 18-44. https://doi.org/10.1002/tax.611002

Schaminée, J. H. J., Chytrý, M., Hennekens, S. M., Janssen, J. A. M., Knollová, I., Rodwell,J. S., Tichý, L., \& data providers (2018). Updated crosswalk of the revised EUNIS Habitat Classification with the European vegetation classification and indicator species for the EUNIS grassland, shrubland and forest types. Report to the European Environment Agency. Wageningen: Wageningen Environmental Research.
Shelyag-Sosonko, Y. R. (Ed.). (1996). Red Book of Ukraine. Plantworld. Kyiv: Ukrainska Entsiklopedia. (In Ukrainian)

Slyusarenko, L. P. (1977). Stipa L. genus Feathergrass. In N. N. Tsvelev (Ed.), Cereals of Ukraine (Anatomical-morphological, karyosystematic and ecological-phytocoenotic review) (pp. 405-424). Kyiv: Naukova Dumka. (In Russian)

Tichý, L. (2002). JUICE, software for vegetation classification. Journal of Vegetation Science, 13, 451453. https://doi.org/10.1111/j.1654-1103.2002. tb02069.x

Tzvelev, N. N. (1986). On Feather grass (Stipa L., Gramineae) of Ukraine. Bulletin of Moscow Society of Naturalists. Ser. Biological, 91(1), 116-124. (In Russian)

Vynokurov, D., Didukh, Y., Krasova, O., Lysenko, H., Goncharenko, I., Dmytrash-Vatseba, I., Chusova, O., Shyriaieva, D., Kolomiychuk, V., Moysiyenko, I. (2020). Eastern European Steppe Database. Vegetation Classification and Survey, 1, 149-150. https://doi.org/10.3897/ VCS/2020/60520

\section{Поширення видів роду Stipa в Україні за матеріалами фітосоціологічних баз даних}

Анна Куземко *, Денис Винокуров, Дарія Ширяєва

Інститут ботаніки ім. М.Г. Холодного НАН України, вул. Терещенківська, 2, Київ, 01601, Україна; * anyameadow.ak@gmail.com

Стаття присвячена з'ясуванню сучасного стану поширення в Україні видів роду Stipa з використанням фітосоціологічних баз даних. Основними завданнями було створити карти їх поширення та з'ясувати приуроченість видів роду Stipa до одиниць класифікації біотопів EUNIS.

У відібраному масиві даних відібрано описи за участі 16 з 27 видів роду Stipa, визнаних у статусі виду в Номенклатурному Чеклисті вищих судинних рослин України. Загалом було виявлено 4888 описів за участі видів роду Stipa. Серед видів роду найбільшу репрезентативність у масиві даних має S. capillata, який було виявлено у 38,1 \% описів. За показником константності у проаналізованому масиві даних цей вид посідає друге місце, а за середнім ненульовим проективним покриттям третє місце. За результатами аналізу карт поширення видів встановлено, що S. capillata має широке розповсюдження у лісостеповій та степовій зонах. Stipa lessingiana теж має значне поширення, але воно переважно обмежене степовою зоною. Для двох видів S. borysthenica i S. tirsa встановлено значно менше поширення, ніж наводиться у літературних джерелах, зокрема у Червоній та Зеленій книгах. Решта видів роду мають дуже обмежене поширення. Аналіз біотопічної приуроченості видів 
роду Stipa показав, що вони трапляються у десяти типах трав'яних біотопів третього рівня ієрархії за класифікацією EUNIS. Переважна більшість видів має екологічний оптимум у біотопах типу R1B Continental dry grassland (true steppe). Найширшу амплітуду за представленістю у різних типах біотопів має S. capillata. Також широкий діапазон типів біотопів характерний для S. pulcherrima, S. lessingiana, S. pennata i S. ucrainica. Види, які слабо представлені у вибірці (S. zalesskii, S. transcarpatica, S. adoxa, S. asperella i S. dasyphy/la), трапляються у небагатьох або лише в одному типі біотопів.

Таким чином, отримані результати показали, що переважна більшість видів роду Stipa в Україні $\epsilon$ рідкісними і потребують охорони на національному рівні. Інша ситуація зі S. capillata, репрезентативність якого у виборці виявилася дуже високою. Його присутність практично в усіх типах трав'яних біотопів, а також у петрофітних, чагарникових і навіть синантропних, свідчить про високу адаптаційну здатність виду, його широку екологічну, ценотичну та біотопічну амплітуду. Наші дослідження підтверджують думку про невідповідність S. capillata критеріям щодо включення видів рослин до національних охоронних списків і про необхідність вилучити цей вид із Червоної книги України, але за умови закріплення у національному законодавстві положень щодо охорони біорізноманіття надорганізмового рівня.

Ключові слова: сухі трав'яні екосистеми, екологічний оптимум, класифікація EUNIS, експертна система, біотопи, константність, Червона книга, степ 